DOI: 10.31392/NPU-nc.series14.2019.27.25

УДК 373.3.015.31:159.923.2 (045)

Заря Л. О.

\title{
Сутність самосвідомості молодших школярів
}

У статті розкривається сутність свідомості як основи самосвідомості молодших школярів. Відмічається, що проблема самосвідомості молодших школярів є наразі актуальною, одним із важливих наукових та практичних завдань сучасності. Автор вказує, що поняття свідомість і самосвідомість $\epsilon$ близькими але не тотожними. 3'ясовується, що поняття свідомість і самосвідомість уміщують різні структурні елементи психічної діяльності молодшого школяра, які грунтуються на оцінки, самооцінки себе та свого життєвого оточення. Визначається, що свідомість спрямовує молодших школярів на більш високий щабель у здатності сприймати інформацію. Стверджується, що розвиток самосвідомості молодшого школяра є процесом, який вимагає сторонньої допомоги. Аби оцінювати власну поведінку, молодший школяр спочатку має засвоїти відповідні норми, правила, навчитись оцінювати їх дотримання іншими людьми; лише на цьому грунті - завдяки порівнянню себе з оточенням - він поступово навчиться оцінювати власні дії та вчинки.

Ключові слова: відображення; здатність; свідомість; самосвідомість; сприйняття; усвідомлення; формування.

Актуальність дослідження. Потенційні можливості молодших школярів, сприйняття навколишньої дійсності, відношення до навчання, вимог суспільства залежить від ступеня сформованої психіки. 3 перших років навчання школярі вчаться бути уважними, спостерігати, стежити, запам'ятовувати, уважно слухати, уявляти, думати, висловлюватися. Тим самим розвиваються різні сторони психічних компонентів, до яких відноситься i свідомість,. Вона допомагає молодшим школярам усвідомлювати свої дії, скеровувати їх, оволодівати ними, керувати своєю поведінкою, помічати й виправляти свої вади, точніше i повніше уявляти щодо своїх та інших школярів фізичні і психологічні якості, самостійно або ж за допомогою дорослих оцінювати свої можливості. Свідомість, будучи початковим етапом розвитку дитини, є важливою психологічною якістю, яка має формуватися з перших років навчання учнів в загальноосвітньому закладі. Коли молодші школярі починають самовизначатися, усвідомлювати життєву суть людини, самостійно мислити, з'являється відповідальність за свої дії та слова, зорганізується поведінка відповідно до соціальних норм, розвивається оцінка себе та навколишнього світу, формується самосвідомість.

Аналіз науково-теоретичних джерел показує, що проблема самосвідомості молодших школярів $\epsilon$ наразі актуальною, одним із важливих наукових та практичних завдань сучасності. Будучи науковим інтересом, самосвідомість розглядається різними науками, що породжує різноманітні судження.

Мета статті полягає у тому, щоб розглянути проблему формування у молодших школярів самосвідомості у контексті подолання суперечностей між:

- сучасними вимогами до якості шкільної освіти і недостатнім рівнем ефективності формування самосвідомості молодших школярів;

- спрямованістю вчителів загальноосвітніх закладів та відсутністю єдиного підходу до методів формування самосвідомості молодших школярів.

Виклад основного матеріалу. Одним із важливих положень зазначеної проблеми є те, що без свідомого ставлення молодших школярів до свого існування, оточення, відносин 3 батьками та однолітками неможлива їх сформована самосвідомість. Відповідно виникають питання: що $є$ основою самосвідомості молодшого школяра? Яким чином сформована свідомість може допомогти формуванню його самосвідомості?

Зазначимо, що поняття свідомість і самосвідомість є близькими але не тотожними: це різні структурні елементи психічної діяльності людини. Як визначив психолог М. Боришевський, у домаганнях особистості безпосередньо стикаються об'єкти самосвідомості та свідомості, самооцінка та оцінка [1, с. 35]. Сутнісна характеристики 
свідомості, як основи самосвідомості, розчиняється у розмаїтті суперечливих моделей, методологічних і теоретичних побудов. Уперше об'єктом вивчення поняття «свідомість» стає в Новий час у концепціях філософів Декарта, Спінози, Локка, Лейбниця і Юма. Рівні свідомості, локалізації психічних функцій в головному мозку, в міру формування психічної зрілості, ступені психічного розвитку дитини досліджували багато науковців, зокрема такі вчені як К. Бюлер, А. Валлон,. А. Люблінська, В. Мухіна, Д. Ельконін. 3 огляду досліджень у наукової літератури з'ясовується, що поняття свідомість і самосвідомість уміщують різні структурні елементи психічної діяльності індивіда, які грунтуються на оцінки, самооцінки себе та свого життєвого оточення.

В останні десятиліття з'являються теорії, які постулюють необхідність конвергенції (від лат. convergo «зближаю») всіх основних традицій вивчення феномена свідомості. Вважається, що складовими внутрішньої структури повсякденної свідомості виступають щоденні потреби, інтереси, система цінностей. Вони мають конкретно-соціальні, сьогочасні витоки свого походження. До свідомості належать такі норми та зразки поведінки, звичаї, традиції, котрі мають як історичні, так і соціальні корені [15, с.17].

Нам імпонує висловлювання сучасного американського дослідника, психолога Роберта Орнстейна, який вказав, що слово «свідомість» має безліч значень, серед яких і стан неспання, і розуміння того, що відбувається навколо нас, що ми робимо і що собою представляємо. Відтак можна сказати, що свідомість - це усвідомлення того, що ми щось усвідомлюємо. Вчений прийшов до висновку, що та частина психіки, де сходяться різні рішення, називається свідомістю. Свідомість підключається, коли необхідно довільне, а не автоматичне керування ситуацією або втручання в його хід [4, с. $301-305]$.

Разом 3 тим, незважаючи на досить великий дослідницький інтерес до проблеми свідомості та самосвідомості, багато аспектів свідомості, як найсуттєвіших чинників формування самосвідомості молодшого школяра залишаються недостатньо вивченими та проаналізованими. Актуальність даного дослідження обумовлена значущістю і недостатньою розробленістю означеної проблеми. Отже розглянемо, яким чином можна охарактеризувати свідомість та самосвідомість молодших школярів?

Рівні свідомості, локалізації психічних функцій в головному мозку під час формування психічної зрілості дитини досліджували психологи: Р. Бернс, Л. Божович, В. Бехтерев, К. Бюлер, А. Валлон, К. Гросс, В. Давидов, П. Гальперин, Е. Клаперед, А. Леонтьєв, А. Люблинська, В. Мухіна, Н. Одуєва, Г. Ушаков, А. Пейпер, Ж.В.Ф. Піаже, В. Прейер, К. Роджерс, С. Рубінштейн, І. Сеченов, С. Холл, Д. Ельконін. За визначеннями науковців, свідомість спрямовує молодших школярів на більш високу ступень здатність сприйняття інформації, вона містить чітко виражене цілеспрямоване відображення дійсності. Активне ставлення до дійсності є характерною рисою свідомості як специфічної форми відображення [8, с. 311-313]. Натомість самосвідомість на рівні 5-7 років більшою мірою визначається ступенем конструктивного синтезу уяви, яка їі розвиває.

Дослідження психіатра Г. Ушакова виявили, що у віці 5-7 років рівень свідомості дитини набуває багато нових якостей, оскільки відбувається стрибок у формуванні його індивідуальної свідомості. Розрізняти праву і ліву сторони тіла дитина починає лише 37 років (спочатку на собі, пізніше і на співрозмовниках). Це стає істотним етапом у формуванні уявлення щодо «схеми тіла» та диференціації самосвідомості. 3 цим новим рівнем розвитку свідомості природно розширюються і поглиблюються уявлення дитини щодо свого «Я».

У наступному періоді (7-11 років) продовжується розвиток і бурхливе збагачення обсягу свідомості, чому більшою мірою сприяє початок систематичного навчання дитини в загальноосвітньому закладі. За матеріалами спостережень Ж. Піаже і А. Валлона можна зробити висновок, що до дванадцятирічного віку, при триваючому ускладненні і збагаченні свідомості дитини поняттями, судженнями і висновками, основною вихідною категорією пізнання залишається, поряд з іншими, уявлення [5, с. 311-313]. 
Найпереконливішими видаються погляди науковців, які пов'язують становлення особистості із виникненням у дитини самосвідомості. Стається це у дошкільному віці: ледь оволодівши найпростішими мовленнєвими конструкціями рідної мови, вже трирічна, а то й молодша дитина, спілкуючись 3 дорослими, раптом замовляє: « Я - сам!», « Я - сама!», протестуючи проти допомоги у справі, 3 якою, як їй здається, вона може впоратись без сторонньої підтримки. Це і є моментом, який засвідчує виникнення самосвідомості: адже, виявляючи про свої можливості, дитина започатковує процес ідентифікації себе з тим, що вона робить, виявляє спроможність бачити себе носієм того, що вона може, чім відрізняється від інших, або подібна до них [1, с. 7]. За твердженням М. Сеченова, самосвідомість не можна вважати таємничим явищем; вона - результат, який закономірно виникає під час пізнання, що здійснюється на основі матеріальних процесів у мозку. Самопізнання дитини відбувається за тими самими законами, що й пізнання навколишнього світу, тобто від почуттів до уявлення, й від нього до думки [12, с. 25].

У педагогічному словнику визначено, що у молодшого школяра самосвідомість складається 3 його уявлень про оцінку себе з боку учителя, учнів, батьків, інших людей, що оточують його [6, с. 253].

За твердженням Н. Куліша сприятливі умови для розвитку самосвідомості з'являються вже у старшому дошкільному віці. Вони полягають у зростанні потреби дитини в комунікативній взаємодії з однолітками та розширенням сфери вимог до неї як виконавця різних видів предметно-практичної діяльності 3 боку дорослих [5, с.7]. Дослідник О. Скрипченко вказує, що 3 віком молодших школярів змінюється співвідношення між позитивною і негативною оцінкою ровесників і себе самих. 3 віком молодші школярі поступово стають більш самокритичними.

Згідно визначення науковця Г. Карпової, у молодшому шкільному віці зароджуються елементи самооцінок та оцінок взірців, а також їх наслідування. Третьокласники за цими ознаками поділяються на дві групи. Першу групу становлять школярі, які загалом правильно оцінюють себе і взірець для наслідування. Таких третьокласників нараховується приблизно $30 \%$. Ці діти мають нахил до самовдосконалення, намагаються виробити у собі моральні якості, зокрема чесність, працьовитість тощо. Типовими для багатьох третьокласників другої групи є неадекватна оцінка себе і взірців для наслідування. Це частково пояснюється тим, що учні не аналізують власні дії і якості зі взірцем.

Важливим для усвідомлення самосвідомості молодших школярів $\epsilon$ визначення 3.С. Карпенко, згідно якого фізичні й психічні стани, дії та вчинки учнів молодшого шкільного віку відображаються в них узагальнено, у формі певних уявлень і частково понять. Завдяки цьому і про себе саму дитина починає думати в узагальнених формах, які становлять важливу основу для формування самосвідомості на наступних етапах життя і розвитку [4, c. 149].

У молодшому шкільному віці все точніше і повніше формується уявлення про свої фізичні і психологічні якості та якості оточуючих людей, що призводить до уточнення $\mathrm{i}$ ускладнення «Я- образу» і образів інших людей [16, с. 148]. Як засвідчують психологічні дослідження і виховна практика, розвиток дитини як особистості зумовлюється не лише змістом, спрямованістю, формами організації на неї виховних впливів, а й тим, як вона ставиться до цих впливів, наскільки активно сприймає спрямовані на неї дії зовнішніх агентів [1, c. 7].

Самосвідомість, перш ніж стати важливою внутрішньою детермінантою, механізмом, через який трансформується вплив зовнішнього середовища, сама виникає під впливом цього середовища. Щоб оцінювати власну поведінку, молодший школяр спочатку має засвоїти відповідні норми, правила, навчитись оцінювати їх дотримання іншими людьми; лише на цьому грунті - завдяки порівнянню себе з оточенням - він поступово навчиться оцінювати власні дії та вчинки. Подібно до цього інші зовнішні впливи, наприклад оцінювання іншими людьми поведінки та діяльності дитини, трансформується в самооцінку [1, с. 16-17]. 
Важливою $є$ думка дослідників, що самосвідомість можна сформувати за допомогою конструктивного синтезу уяви, комунікативної взаємодії з однолітками та розширенням сфери вимог до дитини як виконавця різних видів предметно-практичної діяльності.

Отже, результати дослідження показують, що свідомість є одним з важливих чинників самосвідомості, формування iii можливе за допомогою: мови, мотивації, педагогічного впливу, сім’і, діяльності, духовного життя, рефлексивної спрямованості, усвідомлення відчуттів й прагнень, розумових дій, уваги. Аналіз досліджень у філософсько-психологічному аспекті показав, що свідомість $є$ основою самосвідомості, одним 3 важливих чинників формування самосвідомості молодших школярів.

Формуванню свідомості, як основи самосвідомості, необхідно приділяти увагу з перших років навчання дитини в загальноосвітньому закладі. За допомогою школи, сім’ї та соціуму, поступового ускладнення i збагачення молодшого школяра поняттями, судженнями i висновками він може отримувати все необхідне для формування основ самосвідомості. Самосвідомість, будучи діяльністю розуму, допоможе молодшим школярам усвідомленню своєї індивідуальності, своїх поглядів, бажань, відношень, сприйняттю навчального матеріалу. Без розвиненої свідомості не можлива самосвідомість. Різні погляді на дане питання дає змогу визначити, що самосвідомість завдяки послідовному формуванню 3 перших років навчання молодшого школяра в загальних навчальних закладах має бути зорієнтована на: самоаналіз, самооцінку, усвідомлення власного досвіду, знань, мотивів, думок, ідеалів, моралі, відчуттів й прагнень, переживань, емоцій, мислення, інтересів, цінностей, бажань, потреб, мотивів поведінки, пізнавальних ставлень, діяльності, здатність віддавати звіт у своїх діях, переживаннях, думках і почуттях.

Висновки. Розвиток самосвідомості молодшого школяра виявляється процесом, котрий вимагає допомоги. Важливо, що самосвідомі морально-етичні норми правил поведінки успішно засвоюються молодшими школярами, коли учитель не тільки розкриває їх зміст, але i на конкретних прикладах показує, як їх треба виконувати (як вітатися 3 товаришами, старшими і т. п.), а й ретельно стежить за неухильним виконанням. Формуванню самосвідомості необхідно приділяти увагу 3 перших років навчання дитини в загальноосвітньому закладі. За допомогою школи, сім’ї та соціуму, поступового ускладнення i збагачення поняттями, судженнями і висновками молодший школяр має получати все необхідне для формування самосвідомості. Будучи діяльністю розуму, вона допоможе молодшим школярам усвідомленню своєї індивідуальності, своїх поглядів, бажань, відношень, сприйняттю навчального матеріалу. Тобто формування самосвідомості молодшого школяра допоможе розвитку його особистості, котра зможе усвідомлювати свою суб’єктивну, фізичну, психічну, моральну, навчальну, духовну, соціальну реальність. Як наслідок цього, у нього буде розвинена упевненість у своїх силах, відповідальність, самоконтроль, самовиховання, вміння незалежно і вільно мислити.

\section{Література}

1. Боришевський М.Й. Особистість у вимірах самосвідомості [монографія]. Суми : Видавничий будинок «Еллада», 2012. 608 с.

2. Карпенко 3.С. Психологические особенности самоопределения младших школьников : дисс. ... канд. психол. наук : спец. 19.00.07 / 3.С. Карпенко. - Київ, 1999. - 169 с.

3. Куліш Н.М. Розвиток самосвідомості обдарованих дітей у спільній діяльності: автореф. дис. на здоб/ наук. ступ. канд. псих. наук / Н.М Куліш. - Київ, 2003. - 19 с.

4. Орнстейн Роберт. Эволюция сознания, Length: 382 pages, Published on Apr 24, 2015.

5. Павелкін Р.В. Розвиток моральної свідомості та самосвідомості у дитячому віці: монографія. Рівне: Волинськи обериги, 2004. 248 с.

6. Педагогический энциклопедический словарь; редкол. : М.М. Безруких, В.А. Болотов, Л.С. Глебова и др. - Москва: Большая Российская энциклопедия, 2002. - 528 с.

7. Прист Стивен. Теории сознания. Перевод с английского языка и предисловие А.Ф. Грязнова. Люберцы: Идея пресс, 2000. - 287 с.

8. Психология познания. Сост. и общая редакция Л.В. Куликова. СПб. : Питер, 2001. 480 с. 
9. Психология самосознания. Хрестоматия / Редактор-составитель Д.Я. Райгородский. - Самара : Изд. Дом «Бахрам-М», 2003. - 672 с.

10. Райл Г. Понятие сознания. Москва : Идея-Пресс, Дом интеллектуальной книги, 1999. 408 с.

11. Сепетий Д.П. Свідомість як суб'єктивність: таємниця Я. Запоріжжя : ДМУ, 2011. 256 с.

12. Сеченов М.И. Избранные философские и психологические произведения. - М., 1947

13. Спиркин А.Г. Происхождение сознания. М. : Госполитиздат, 1960. 471 с.

14. Спиркин А.Г. Сознание и самосознание. М. : ИПЛ, 1972. 303 с.

15. Формування національної самосвідомості: історія, культура, мова, педагогіка. Монографія. Донецьк : Ноулідж, 2013. - 201с.

16. Чамата П.Р. Вопросы самосознания личности в советской психологи // Психологична наука в СССР. М.: Изд-во АПН РСФСР, 1960. - Т.2

\section{Про автора:}

Заря Лариса Олександрівна, кандидат педагогічних наук, доцент кафедри фортепіано Харківської гуманітарно-педагогічної академії; ORCID: 0000-0001-5316-463X

\section{The essence junior schoolchildren's self consciousness}

Zaria L. O.

The article reveals the essence of consciousness as the basis for the consciousness of younger pupils. It is noted that the problem of self-consciousness of younger pupils is currently relevant, and one of the important scientific and practical tasks of today. The purpose of solving the problem of the formation of selfconsciousness among younger pupils is also disclosed. The author points out that the concepts of consciousness and self-consciousness are close but not identical. A variety of perspectives on the nature of consciousness, formulated by researchers and scientists, have been revealed. It turns out that the concepts of consciousness and self-consciousness contain various structural elements of the mental activity of younger pupils, which are based on the self-esteem and the esteem of one's background. The levels of consciousness and their elements are stated. It is determined that consciousness directs younger pupils to a higher degree of ability to perceive information. It is said that the development of consciousness, as well as of selfconsciousness of younger pupils, is a process that requires help from outside.

The author determines that self-consciousness, which is based on consciousness, owing to the step-bystep formation from the first years of the study of a junior schoolchild at the general educational institutions, should be oriented to the following: self-analysis, self-esteem, awareness of one's own experience, knowledge, motives, thoughts, ideals, morals, feelings and aspirations, anxiousness, emotions, thinking, interests, values, desires, needs, motives of behavior, cognitive attitudes, activities, ability to report in one's actions, experiences, thoughts and feelings. It has been pointed out that, before becoming an important internal determinant and the mechanism through which the influence of the environment is transformed, selfconsciousness itself arises under the influence of that environment. In order to evaluate their own behavior, the elementary schoolchild must first learn the relevant norms, rules, and learn how to evaluate their compliance by the other people; only on this ground - by comparing oneself to one's surroundings - will he/she gradually learn to evaluate his/her own actions and deeds. The results of the present study showed that consciousness is one of the important factors of self-consciousness, its formation is possible through the following: language, motivation, pedagogical influence, family, activity, spiritual life, reflexive orientation, awareness of feelings and aspirations, mental actions, and attention. The analysis of studies in philosophical and psychological aspect has shown that consciousness is the basis of self-consciousness, one of the important factors in the formation of self-consciousness of younger schoolchildren.

Keywords: ability; awareness; consciousness; formation; reflection; self-consciousness.

\section{References}

1. Boryshevsky M.Y. Personality in the dimensions of self-consciousness [monograph]. Sumy: Publishing House "Hellas", 2012. 608 p. [in Ukrainian]

2. Karpenko Z.S. Psihologicheskie osobennosti camoopredelenija mladchih chkolnikov : dis... kand. psihol. nauk : spes. 19.00.07. [Thesis PhD (Psychological Sciences)]. Kyiv, 1999. 169 p. [in Russian]

3. Kulish N.M. Development of self-awareness of gifted children in joint activities : [author's abstract of the Psychological Sciences Candidate's Dissertation]. Kyiv, 2003. 19 p. [in Ukrainian]

4. Ornstein Robert. Evolution of Consciousness, Length: 382 pages, Published on April 24, 2015. [in Russian] 
5. Pavelkin R.V. Development of moral consciousness and self-consciousness in childhood: monograph. Rivne: Volynsky Oberigy, 2004. 248 p. [in Ukrainian] Russian]

6. Pedagogicheski enziklopedicheski slovar M. : Bolchaya Rosiya enziklopediya, 2002. 528 p. [in

7. Priest Stephen. Theories of Consciousness. Translated from the English language and the foreword by A.F. Gryaznov. - Lyubertsy: Idea-Press, 2000. - 287 p. [in Russian]

8. Psychology of cognition. Compilation and the general edition by L.V. Kulykov. St. Petersburg: Piter, 2001. 480 p. [in Russian]

9. Psychology of self-cognition. Editor-compiler D.Ya. Raygorodsky. Samara: Izd. Dom «Bahram-M», 2003. - 672 p. [in Russian]

10. Ryle G. The concept of consciousness. M. : Idea-Press, House of Intelligent Book, 1999. 408 p. [in Russian]

11. Sepetiy D.P. Consciousness as subjectivity: the secret of I / D.P. Septiy. - Zaporozhye: DMU, 2011. 256 p. [in Ukrainian]

12. Sechenov M. Izbranni philosophical and psychological works. - M., 1947 [in Russian] Russian]

13. Spirkin A.G. The Origin of consciousness / A.G. Spirkin. M.: Gospolitizdat, 1960. 471 p. [in

14. Spirkin A.G. Consciousness and self-consciousness. M.: IPL, 1972. 303 p. [in Russian]

15. Formation of national consciousness: history, culture, language, pedagogy. Monograph. Donetsk: Knowledge, 2013. 201c. [in Ukrainian]

16. Chamata P.R. Questions of personality consciousness in Soviet psychologists // Psychological science in the USSR. Moscow: Publisher of the Academy of Pedagogical Sciences of the RSFSR, 1960. T.2. [in Russian]

About the author:

Zaria Larysa Oleksandrivna, Candidate of Pedagogical Sciences (Ph.D.). Associate Professor at the Piano Department, Kharkiv Humanitarian Pedagogical Academy (Kharkiv, Ukraine); ORCID: 0000-00015316-463X 